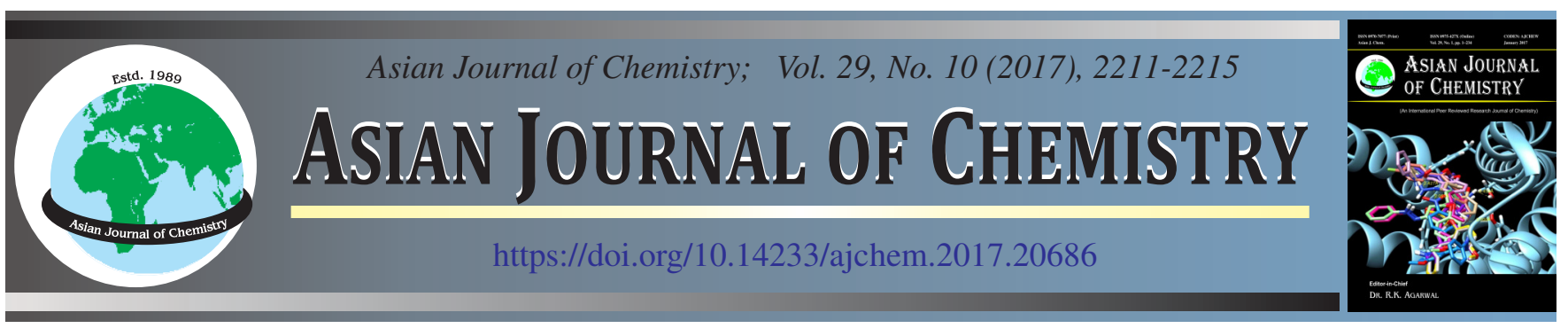

\title{
Rare Earth Elements Behaviour at West Coast of Peninsular Malaysia Rocky Shore Ecosystem Using Saccostrea cucullata as Bioindicator
}

\author{
Y. Kamaruzzaman ${ }^{1, *}$, M. Miskan ${ }^{1}$, F. Fikriah $^{1}$, M.M. Rahman ${ }^{2}$, Ong Meng Chuan $^{3}$ and Hasrizal ShaAri ${ }^{3}$
}

${ }^{1}$ Department of Marine Science, Kulliyyah of Science, International Islamic University Malaysia, Bandar Indera Mahkota, 25200 Kuantan, Pahang, Malaysia

${ }^{2}$ Department of Pharmaceutical Chemistry, Kulliyyah of Pharmacy, International Islamic University Malaysia, Bandar Indera Mahkota, 25200 Kuantan, Pahang, Malaysia

${ }^{3}$ School of Marine and Environment, Universiti Malaysia Terengganu, 21030 Kuala Terengganu, Terengganu, Malaysia

*Corresponding author: Fax: +60 5 716781; Tel:+ 609 5705001; E-mail: kama@iium.edu.my

Received: 4 April 2017;

Accepted: 30 June 2017;

Published online: 31 August 2017;

AJC-18521

\begin{abstract}
This study focuses on the assessment of rare earth elements (REEs) in rocky shore ecosystem along west coast region of Peninsular Malaysia coastal waters, describing their partitioning in selected body part of Saccostrea cucullata and deliberating on interspatial variability. Samples were digested using Teflon Bomb technique and concentrations of 14 naturally occurring REEs were measured using ICP-MS technique, along with selected trace metals for additional data. The REEs fractionation patterns normalized to chondrite were remarkably similar, indicating a common source of the REEs. Consistent REEs abundance patterns were found in all samples, with enrichment of LREE over HREE, which implies that REEs are transported as a coherent group through west coast of Peninsular Malaysia aquatic ecosystems. Quantification of anomalies calculated using values normalized to chondrite data presented ratios higher than unity for $\mathrm{Ce}$ and ratios lower than unity for Eu in all sites. Filter feeder S. cucullata is considered to be highly potential as a bioindicator for REEs, undoubtedly due to its feeding behaviour that is much related to suspended particles as REEs sources. Comparative results showed that the values are considerably below the safety limit, with the exception of $\mathrm{Ce}$ and $\mathrm{Nd}$ in the soft tissue of $S$. cucullata.
\end{abstract}

Keywords: Rare earth elements, Soft tissue, Rocky shore, Chondrite, Saccostrea cucullata.

\section{INTRODUCTION}

Rare earth elements (REEs) are used in enormous magnitudes in the mechanized of industrial goods including lasers, computers, pigments for glass and plastics and additives, where they influence electric, magnetic, or optical features [1]. The demanding use of REEs in the technological industry results in noticeably higher amounts disposed into the surroundings [2]. Rare earth elements incline to be accumulated by biota and have contaminated consequences similar to those of $\mathrm{Cd}, \mathrm{Zn}$ and $\mathrm{Ni}$ [1]. All aquatic invertebrates gather trace elements in their tissues, whether or not these elements are required for metabolism [3]. With respect to REEs, no established biological functions have been described and thus these elements are considered as non-essential in biota. Various elementaccumulating bivalve species show a high abundance and play an important role as bioindicators for pollution in global monitoring programs throughout the world [4]. The objectives of this study are to explore the bioavailability and extent of exposure of REEs in soft tissue of $S$. cucullata from different rocky shore sites along coastal waters of the west coast of
Peninsular Malaysia and to provide the baseline data for the west coast region.

\section{EXPERIMENTAL}

In general, Peninsular Malaysia can be divided into two parts; east coast area (from Kelantan state to East Johor state) and west coast area (from Perlis state to West Johor state). The west coast area is much more developed compared with the east coast area as it is adjacent to the busiest strait in the world, Malacca strait [5,6]. Six study sites have been selected in west coast area, on the basis of the occurrence of the $S$. cucullata and different site characteristics.

Initially, before sampling, site survey has been done to ensure the accessibility to the study sites, as to minimize the sampling time during next sampling session and the availability of the selected bioindicator. Table-1 displayed a list of sampling sites and their locations determined by coordinate along the west coast of Peninsular Malaysia coastal waters. These recorded locations were also useful for further exploration. All samples were taken during the same period, but from different sites to 
characterize the spatial variations in the samples. About 2040 individuals of relatively same size (shell length of 4-5 cm) were hand collected during low tide period and placed in polyethylene bags with native water. They were endorsed to empty their guts for $24 \mathrm{~h}$, following the method by Bustamante and Miramand [7], with little modification. All samples were assigned in plastic loads, sealed, categorized and saved at 4$6{ }^{\circ} \mathrm{C}$ during transportation to the laboratory where the samples were cleaned with running Mili-Q water $(18.2 \Omega)$ to eliminate sediment and salt particles prior to store frozen. After parameter measurement and tissue extraction, obtained soft tissues were oven dried at $60{ }^{\circ} \mathrm{C}$ for 3 days. Oven-dried samples were then minced to a powder and kept at room temperature until analysis.

TABLE-1

LIST OF SAMPLING SITES AND THEIR LOCATIONS

\begin{tabular}{clcc}
\hline No. & \multicolumn{1}{c}{ Site } & Latitude & Longitude \\
\hline 1 & Pulau Sayak, Kedah & $5.6548^{\circ} \mathrm{N}$ & $100.3340^{\circ} \mathrm{E}$ \\
2 & Batu Feringghi, Penang & $5.4799^{\circ} \mathrm{N}$ & $100.2616^{\circ} \mathrm{E}$ \\
3 & Teluk Senangin, Perak & $4.3111^{\circ} \mathrm{N}$ & $100.5701^{\circ} \mathrm{E}$ \\
4 & Teluk Batik, Perak & $4.1853^{\circ} \mathrm{N}$ & $100.6093^{\circ} \mathrm{E}$ \\
5 & Tanjung Bidara, Malacca & $2.2956^{\circ} \mathrm{N}$ & $102.0787^{\circ} \mathrm{E}$ \\
6 & Batu Pahat, Johor & $1.7937^{\circ} \mathrm{N}$ & $102.8876^{\circ} \mathrm{E}$ \\
\hline
\end{tabular}

Glassware used was treated with $10 \%$ nitric acid solution in advance for contamination prevention. The digestion and analytical procedures were executed using the Teflon Bomb method by Kamaruzzaman et al. [8], with little modification. Analysis of REEs was carried out using ICP-MS Perkin Elmer Elan 9000 system using its standard configuration, following method by Kamaruzzaman et al. [9] with modification to enhance the accuracy. The $\mathrm{HNO}_{3}$ (Merck, Suprapur) used for measurement was less than $2 \%$ as to minimize the damage to the interference and to minimize isobaric molecular interferences. Aliquots were typically diluted 10 times for analysis with $2 \%$ $\mathrm{HNO}_{3}$, made using a combination of pure $\mathrm{HNO}_{3}$ (Merck, Suprapur) and Milli-Q water. Results were quantified via an external calibration curve generated from the response obtained from serial dilutions of a multi-element calibration standard. The isotopes measured were ${ }^{139} \mathrm{La},{ }^{140} \mathrm{Ce},{ }^{141} \mathrm{Pr},{ }^{142} \mathrm{Nd},{ }^{152} \mathrm{Sm},{ }^{153} \mathrm{Eu}$, ${ }^{158} \mathrm{Gd},{ }^{159} \mathrm{~Tb},{ }^{164} \mathrm{Dy},{ }^{165} \mathrm{Ho},{ }^{166} \mathrm{Er},{ }^{169} \mathrm{Tm},{ }^{174} \mathrm{Yb}$ and ${ }^{175} \mathrm{Lu}$. Results achieved were blank corrected and expressed as $\mu \mathrm{g} \mathrm{g}^{-1}$ dry weight. Recovery procedure was executed using Standard reference material BCR 668 Mussel Tissue purchased from Institute for Reference Materials and Measurements (IRMM), Belgium.

One-way analysis of variance (ANOVA) was engaged for assessment of dissimilarity and noteworthy differences observed between REEs in different sites. All comparisons were made at least at the $95 \%(p<0.05)$ and $99 \%(p<0.01)$ level of significance. The analytical results and field data were compiled to form a multi-elemental database using Excel 2013 software (Microsoft, Washington, USA) and SPSS software (SPSS Inc., Chicago, USA). To omit the overwhelming Oddo-Harkins' effect in the REEs concentration pattern of samples, concentration data were divided by the average chondrite taken from Mcdonough and Sun [10] and shale concentrations taken from Taylor and McLennan [11]. The anomalies were defined as
$\mathrm{REE}_{\mathrm{n}} / \mathrm{REE}_{\mathrm{n}}{ }^{*}$ where $\mathrm{REE}_{\mathrm{n}}$ is the shale-normalized or chondritenormalized REE concentration while REE is the calculated normalized concentration. Following the previous studies [1214], the magnitude of the REEs anomaly were calculated based on the equation:

$$
\mathrm{REE}_{\mathrm{n}} / \mathrm{REE}_{\mathrm{n}}{ }^{*}=2 \mathrm{REE}_{\mathrm{n}} /\left([\mathrm{REE}]_{\mathrm{n}-1}+[\mathrm{REE}]_{\mathrm{n}-1}\right)
$$

where $n=1,2,3 \ldots$ in the order of lanthanide series. Adopted from (1), the anomalies of $\mathrm{Ce}$ and $\mathrm{Eu}$ are calculated as:

$$
\begin{gathered}
\mathrm{Ce} / \mathrm{Ce}^{*}=3[\mathrm{Ce}] /([\mathrm{La}]+2[\mathrm{Nd}]) \\
\mathrm{Ce} / \mathrm{Ce}^{*}=3\left(\mathrm{Ce}_{\text {sample }} / \mathrm{Ce}_{\mathrm{N}}\right) /\left[\left(\mathrm{La}_{\text {sample }} / \mathrm{La}_{\mathrm{N}}\right)+2\left(\mathrm{Nd}_{\text {sample }} / \mathrm{Nd}_{\mathrm{N}}\right)\right](2 \mathrm{~b}) \\
\mathrm{Eu} / \mathrm{Eu}^{*}=[\mathrm{Eu}] /([\mathrm{Sm}] \times[\mathrm{Gd}])^{1 / 2}
\end{gathered}
$$

where $\mathrm{Ce}, \mathrm{La}, \mathrm{Nd}, \mathrm{Eu}, \mathrm{Sm}$ and $\mathrm{Gd}$ are a concentration in the sample while the subscript $\mathrm{N}$ refers to the chondrite concentration. Therefore, the positive anomaly is defined as the REE/ REE* value greater than unity while negative anomaly is defined as the REE/REE* value less than unity. For the calculation of $(\mathrm{La} / \mathrm{Yb})_{\mathrm{N}}$, the equation was expressed as:

$$
(\mathrm{La} / \mathrm{Yb})_{\mathrm{N}}=\left(\mathrm{La}_{\text {sample }} / \mathrm{La}_{\mathrm{N}}\right) /\left(\mathrm{Yb}_{\text {sample }} / \mathrm{Yb}_{\mathrm{N}}\right)
$$

where $\mathrm{N}$ is the concentration of $\mathrm{La}$ and $\mathrm{Yb}$ in Post-Archean Australian Sedimentary rocks (PAAS). Post-Archean Australian Sedimentary rocks values was obtained from Taylor and McLennan [11]. For the calculation of total REEs, LREE and HREE, the calculation method were as follow:

$$
\Sigma \mathrm{LREE}=\mathrm{La}+\mathrm{Ce}+\mathrm{Pr}+\mathrm{Sm}
$$

$\Sigma \mathrm{HREE}=\mathrm{Eu}+\mathrm{Gd}+\mathrm{Tb}+\mathrm{Dy}+\mathrm{Ho}+\mathrm{Er}+\mathrm{Tm}+\mathrm{Yb}+\mathrm{Lu}(6)$

$$
\Sigma \text { REE }=\Sigma \text { LREE }+\Sigma \text { HREE }
$$

\section{RESULTS AND DISCUSSION}

Rare earth elements distribution in S. cucullata: The mean rare earth elements (REEs) concentrations with standard deviation in the soft tissue of $S$. cucullata are illustrated in Table-2. Result by using ANOVA indicated that there are significant differences between concentrations of all REEs among sampling sites $(\mathrm{p}<0.05)$. By calculating the average of REEs for all sites, Ce was the most abundant element while Lu was the least abundant element.

Table-3 presented the pattern of REEs of the soft tissue of studied S. cucullata in decreasing pattern, dividing it into LREE and HREE distribution. The pattern was quite consistent through all sites. In general, the abundance of REEs concentrations in the soft tissue of $S$. cucullata follows the order of $\mathrm{Ce}>\mathrm{Nd}>\mathrm{La}>\mathrm{Sm}>\mathrm{Pr}$ for the LREE and $\mathrm{Gd}>\mathrm{Dy}>\mathrm{Er}>\mathrm{Yb}$ $>\mathrm{Ho}>\mathrm{Tb}>\mathrm{Eu}>\mathrm{Tm}>\mathrm{Lu}$ for the HREE. The REEs accumulation patterns in this oyster species indicate enrichment of LREE compared to HREE.

Rare earth elements behaviour in S. cucullata: The total concentration of REEs ( $\Sigma$ REE), light REEs ( $\Sigma$ LREE), heavy REEs ( $\Sigma$ HREE) and its indicator ratios of $\Sigma$ LREE/ $\Sigma$ HREE, $\mathrm{La} / \mathrm{Yb}, \mathrm{La} / \mathrm{Sm}, \mathrm{Ce} / \mathrm{La}, \mathrm{Eu} / \mathrm{Sm}$ and $\mathrm{Yb} / \mathrm{Sm}$ of the soft tissue of S. cucullata are presented in Table-4. LREE enrichment is over HREE as indicated by the higher mean values of $\Sigma$ LREE compared to $\Sigma$ HREE. The mean ratio of $\Sigma$ LREE/ $\Sigma$ HREE between sites did not show significant changes from 3.20 to 5.85. Based 


\begin{tabular}{|c|c|c|c|c|c|c|}
\hline \multicolumn{7}{|c|}{$\begin{array}{l}\text { TABLE-2 } \\
\text { MEAN CONCENTRATION ( } \mu \mathrm{g} \mathrm{g}^{-1} \text { DRY WEIGHT) OF } \Sigma \text { REE IN SOFT TISSUE OF } S \text {. cucullata }\end{array}$} \\
\hline & P. Sayak & Bt. Feringghi & Tlk. Senangin & Tlk. Batik & Tg. Bidara & Bt. Pahat \\
\hline $\mathrm{La}$ & $0.71 \pm 0.39$ & $0.30 \pm 0.17$ & $1.44 \pm 0.61$ & $0.79 \pm 0.82$ & $2.50 \pm 0.55$ & $5.40 \pm 3.03$ \\
\hline $\mathrm{Ce}$ & $1.78 \pm 0.82$ & $0.69 \pm 0.42$ & $3.51 \pm 1.31$ & $2.52 \pm 2.74$ & $8.45 \pm 2.81$ & $13.24 \pm 6.62$ \\
\hline $\operatorname{Pr}$ & $0.21 \pm 0.11$ & $0.08 \pm 0.06$ & $0.45 \pm 0.16$ & $0.31 \pm 0.35$ & $4.97 \pm 2.26$ & $1.56 \pm 0.74$ \\
\hline $\mathrm{Nd}$ & $0.97 \pm 0.46$ & $0.42 \pm 0.27$ & $1.90 \pm 0.64$ & $1.39 \pm 1.54$ & $4.93 \pm 1.93$ & $6.22 \pm 2.72$ \\
\hline Sm & $0.28 \pm 0.15$ & $0.12 \pm 0.10$ & $0.49 \pm 0.17$ & $0.43 \pm 0.49$ & $1.61 \pm 0.63$ & $1.54 \pm 0.47$ \\
\hline $\mathrm{Eu}$ & $0.03 \pm 0.03$ & $0.01 \pm 0.01$ & $0.05 \pm 0.03$ & $0.06 \pm 0.07$ & $1.61 \pm 0.71$ & $0.27 \pm 0.07$ \\
\hline Gd & $0.33 \pm 0.16$ & $0.14 \pm 0.12$ & $0.56 \pm 0.19$ & $0.49 \pm 0.56$ & $1.76 \pm 0.62$ & $1.81 \pm 0.51$ \\
\hline $\mathrm{Tb}$ & $0.03 \pm 0.02$ & $0.01 \pm 0.02$ & $0.07 \pm 0.03$ & $0.08 \pm 0.09$ & $1.28 \pm 0.51$ & $0.23 \pm 0.05$ \\
\hline Dy & $0.28 \pm 0.13$ & $0.14 \pm 0.12$ & $0.52 \pm 0.19$ & $0.49 \pm 0.56$ & $0.45 \pm 0.08$ & $1.33 \pm 0.17$ \\
\hline Ho & $0.03 \pm 0.02$ & $0.01 \pm 0.02$ & $0.07 \pm 0.03$ & $0.08 \pm 0.09$ & $0.52 \pm 0.20$ & $0.20 \pm 0.03$ \\
\hline Er & $0.12 \pm 0.05$ & $0.05 \pm 0.05$ & $0.23 \pm 0.08$ & $0.22 \pm 0.24$ & $0.63 \pm 0.19$ & $0.55 \pm 0.09$ \\
\hline $\mathrm{Tm}$ & $0.00 \pm 0.00$ & $0.00 \pm 0.00$ & $0.01 \pm 0.01$ & $0.02 \pm 0.02$ & $0.43 \pm 0.17$ & $0.04 \pm 0.01$ \\
\hline $\mathrm{Yb}$ & $0.08 \pm 0.03$ & $0.03 \pm 0.03$ & $0.14 \pm 0.04$ & $0.12 \pm 0.12$ & $0.18 \pm 0.01$ & $0.35 \pm 0.10$ \\
\hline $\mathrm{Lu}$ & $0.00 \pm 0.00$ & $0.00 \pm 0.00$ & $0.00 \pm 0.00$ & $0.00 \pm 0.00$ & $0.20 \pm 0.08$ & $0.00 \pm 0.00$ \\
\hline
\end{tabular}

TABLE-3

DECREASING PATTERN OF RARE EARTH ELEMENTS OCCURRENCES ( $\mu \mathrm{g} \mathrm{g}^{-1}$ DRY WEIGHT) IN SOFT TISSUE OF $S$. cucullata

\begin{tabular}{|c|c|c|}
\hline \multirow{2}{*}{ Site } & \multicolumn{2}{|c|}{ Element pattern } \\
\hline & Low rare earth elements & High rare earth elements \\
\hline P. Sayak & $\mathrm{Ce}>\mathrm{Nd}>\mathrm{La}>\mathrm{Sm}>\mathrm{Pr}$ & $\mathrm{Gd}>\mathrm{Dy}>\mathrm{Er}>\mathrm{Yb}>\mathrm{Ho}>\mathrm{Eu}>\mathrm{Tb}>\mathrm{Tm}>\mathrm{Lu}$ \\
\hline Blk. Pulau & $\mathrm{Ce}>\mathrm{Nd}>\mathrm{La}>\mathrm{Sm}>\mathrm{Pr}$ & $\mathrm{Gd}>\mathrm{Dy}>\mathrm{Er}>\mathrm{Yb}>\mathrm{Ho}>\mathrm{Tb}>\mathrm{Eu}>\mathrm{Tm}>\mathrm{Lu}$ \\
\hline Bt. Feringghi & $\mathrm{Ce}>\mathrm{Nd}>\mathrm{La}>\mathrm{Sm}>\mathrm{Pr}$ & $\mathrm{Gd}>\mathrm{Dy}>\mathrm{Er}>\mathrm{Yb}>\mathrm{Ho}>\mathrm{Tb}>\mathrm{Eu}>\mathrm{Tm}>\mathrm{Lu}$ \\
\hline Tlk. Senangin & $\mathrm{Ce}>\mathrm{Nd}>\mathrm{La}>\mathrm{Sm}>\mathrm{Pr}$ & $\mathrm{Gd}>\mathrm{Dy}>\mathrm{Er}>\mathrm{Yb}>\mathrm{Ho}>\mathrm{Tb}>\mathrm{Eu}>\mathrm{Tm}>\mathrm{Lu}$ \\
\hline Tlk. Batik & $\mathrm{Ce}>\mathrm{Nd}>\mathrm{La}>\mathrm{Sm}>\mathrm{Pr}$ & $\mathrm{Dy}>\mathrm{Gd}>\mathrm{Er}>\mathrm{Yb}>\mathrm{Ho}>\mathrm{Tb}>\mathrm{Eu}>\mathrm{Tm}>\mathrm{Lu}$ \\
\hline Bt. Pahat & $\mathrm{Ce}>\mathrm{Nd}>\mathrm{La}>\mathrm{Pr}>\mathrm{Sm}$ & $\mathrm{Gd}>\mathrm{Dy}>\mathrm{Er}>\mathrm{Yb}>\mathrm{Eu}>\mathrm{Tb}>\mathrm{Ho}>\mathrm{Tm}>\mathrm{Lu}$ \\
\hline
\end{tabular}

TABLE-4

MEAN CONCENTRATION OF EREE, $\Sigma$ LREE, LHREE, LREE/HREE, Ce/La IN SOFT TISSUE OF $S$. cucullata

\begin{tabular}{lccccc}
\hline \multicolumn{1}{c}{ Site } & $\begin{array}{c}\Sigma \text { REE } \\
\left(\mu \mathrm{g} \mathrm{g}^{-1}\right)\end{array}$ & $\begin{array}{c}\Sigma \mathrm{LREE} \\
\left(\mu \mathrm{g} \mathrm{g}^{-1}\right)\end{array}$ & $\begin{array}{c}\Sigma \mathrm{HREE} \\
\left(\mu \mathrm{g} \mathrm{g}^{-1}\right)\end{array}$ & $\begin{array}{c}\text { LREE/ } \\
\text { HREE }\end{array}$ & $\mathrm{Ce} / \mathrm{La}$ \\
\hline P. Sayak & 6.62 & 3.95 & 0.89 & 4.42 & 2.51 \\
Blk. Pulau & 2.96 & 1.61 & 0.39 & 4.16 & 2.32 \\
Bt. Feringghi & 12.32 & 7.35 & 1.68 & 4.37 & 2.69 \\
Tlk. Senangin & 9.86 & 5.43 & 1.57 & 3.47 & 3.17 \\
Tlk. Batik & 30.53 & 21.39 & 6.69 & 3.20 & 3.33 \\
Bt. Pahat & 38.60 & 27.96 & 4.78 & 5.85 & 2.45 \\
\hline
\end{tabular}

on this ratio also displayed that LREE to be enriched compared with HREE in the samples. The correlation between LREE in the samples was measured by the determination of $\mathrm{Ce} / \mathrm{La}$, which indicated that both ratios were consistent in most of the studied sites.

Rare earth elements anomalies in S. cucullata: Chondrite has been used for normalization of REEs since the bulk composition of the globe is assumed to be close to chondrite meteorites that represent the primordial earth $[15,16]$. Referring to Fig. 1, Ce and Eu deviations in the chondrite-normalized REEs pattern are expected as these REEs are expected to behave differently from the other REEs due to changes in their oxidation states in a specific environment. They behave differently, in which $\mathrm{Ce}^{3+}$ under oxidizing conditions becomes insoluble $\mathrm{Ce}^{4+}$ while under reducing condition $\mathrm{Eu}^{3+}$ becomes $\mathrm{Eu}^{2+}$ [16-19].

Fig. 1 displays the chondrite-normalized pattern for REEs concentrations in soft tissue of $S$. cucullata. Results of the analysis presented patterns of LREE enrichment, gradual downward pattern and depletion through HREE concen-

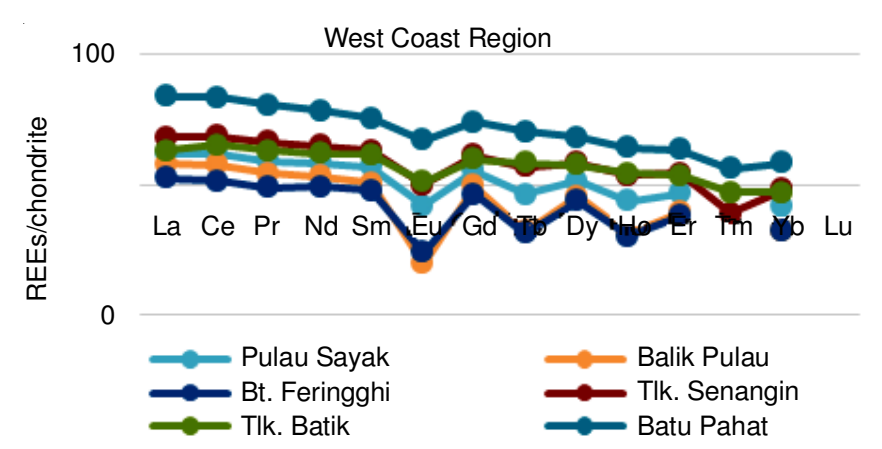

Fig. 1. Chondrite-normalized plots for the REEs in the soft tissue of $S$. cucullata

trations. All sites clearly show negative Eu anomaly. However for $\mathrm{Ce}$, which was expected to deviate as a result of being redox element displaying a little and almost no anomaly.

Table-5 presenting indicator ratios of $\mathrm{Ce} / \mathrm{Ce} *, \mathrm{Eu} / \mathrm{Eu}^{*}$ and $(\mathrm{La} / \mathrm{Yb}) \mathrm{N}$ in the soft tissue of $S$. cucullata. Through the calculation of indicator ratio, results indicated that all sites were displaying positive $\mathrm{Ce}$ anomaly. Indicator of $\mathrm{Eu} / \mathrm{Eu}^{*}$ across sites displayed identical ratios with all sites presenting ratios less than unity, indicating the monopoly of negative Eu anomaly. (La/Yb)N ranging from between 4.38 to 10.89 , displaying a large variation of LREE enrichment within sites. Balik Pulau revealing highest $(\mathrm{La} / \mathrm{Yb}) \mathrm{N}$ while Tlk. Batik site was the lowest. In general, the soft tissue of $S$. cucullata was characterized by $\mathrm{Ce} / \mathrm{Ce}^{*}$ higher than unity and $\mathrm{Eu} / \mathrm{Eu}^{*}$ less than unity.

Cerium and $\mathrm{Eu}$ in the chondrite-normalized REEs pattern in S. cucullata display a range of anomalies. There is tendency fora positive $\mathrm{Ce}$ anomaly and a negative $\mathrm{Eu}$ anomaly within 


\begin{tabular}{lccc}
\hline \multicolumn{5}{c}{ TABLE-5 } \\
\multicolumn{4}{c}{$\begin{array}{c}\text { INDICATOR RATIOS OF Ce/Ce*, Eu/Eu* AND } \\
\text { (La/Yb)N IN SOFT TISSUE OF S. cucullata }\end{array}$} \\
\hline \multicolumn{1}{c}{ Site } & Ce/Ce* & Eu/Eu* & $(\mathrm{La} / \mathrm{Yb}) \mathrm{N}$ \\
\hline P. Sayak & 1.20 & 0.27 & 6.25 \\
Blk. Pulau & 1.24 & 0.06 & 10.89 \\
Bt. Feringghi & 1.09 & 0.12 & 6.59 \\
Tlk. Senangin & 1.25 & 0.32 & 6.22 \\
Tlk. Batik & 1.31 & 0.41 & 4.38 \\
Bt. Pahat & 1.30 & 0.49 & 10.56 \\
\hline
\end{tabular}

soft tissue of $S$. cucullata are derived from particulate matter of sediment and might be related to the deviation in seawater. Weltje et al. [17] clarified that water sample possibly included suspended particulate particles $<0.45 \mu \mathrm{m}$, i.e., colloids. It is evident that colloids in seawater are closely related with rock oyster feeding behaviour as experimented by Wisely and Reid [20]. Certainly, it was exposed by other reports that the colloidal material is preferentially enriched in $\mathrm{Ce}$ in river water and second most concentrated REE in the dissolved particulate matter in lake water [17]. Whereas in seawater, the certain process by oxide particles which take the insoluble $\mathrm{Ce}(\mathrm{IV})$ with them giving the results of positive Ce anomalies [16]. The chondrite-normalized pattern in this study strongly suggests that the REEs accumulated by $S$. cucullata was derived mostly from indigenous rocks. Granite is the dominant rock of the east coast of peninsular Malaysia and thus was the main natural source of REEs supplying the South China Sea [21].

Assessment with maximum permissible concentrations: A report on maximum permissible limits of REEs was reported by Sneller et al. [22], yet, it was limited to Y, La, Ce, Pr, Nd, $\mathrm{Sm}, \mathrm{Gd}$ and Dy, with no limits set for the marine organism by regulation. Thus, comparisons with permissible limits are quantified by comparing with metal data as REEs concentrations seems to be lower compared with these metal value. Metal chosen includes $\mathrm{Hg}, \mathrm{Pb}$ and $\mathrm{Cd}$ due to their lowest limits value compare to other metals. For a valid comparison with maximum permissible limits for food safety, the concentrations of species in this study have been converted into wet weight basis using conversion factor. Such procedure was executed due to most of the safety levels established were expressed on a wet weight basis.

Table-6 displayed maximum permissible limits on selected heavy metals $\left(\mu \mathrm{g} \mathrm{g}^{-1}\right)$ for food safety set by different countries whereas Table-7 presented a comparative analysis of mean values of REEs concentration $\left(\mu \mathrm{g} \mathrm{g}^{-1}\right)$ in wet and dry states of the soft tissue of $S$. cucullata. In comparison with the permissible limits set by the Malaysian Food Regulations 1985 Fourteen Schedule for $\mathrm{Hg}\left(0.5 \mu \mathrm{g} \mathrm{g}^{-1}\right.$ wet weight $), \mathrm{Pb}(2.0 \mu \mathrm{g}$ $\mathrm{g}^{-1}$ wet weight) and $\mathrm{Cd}\left(1.0 \mu \mathrm{g} \mathrm{g}^{-1}\right.$ wet weight), the mean concentrations of REEs in $S$. cucullata on a wet weight basis across the series are lower than the limits, except for $\mathrm{Ce}$ and $\mathrm{Nd}$. These elements presented values higher than $\mathrm{Hg}$ limits, however, do not exceed $\mathrm{Pb}$ permissible limit. With regard to dry weight basis, Ce concentration is also slightly higher than limit sets for $\mathrm{Cd}$, but still lower than limit sets for $\mathrm{Pb}$. Still, this is not a case for $\mathrm{Nd}$. With the exception of $\mathrm{Ce}$ and $\mathrm{Nd}$, the REEs levels across series are lesser than the endorsed guidelines set by by the Brazilian Ministry of Health, the Ministry of Public

\begin{tabular}{lccccc}
\multicolumn{5}{c}{ TABLE-6 } \\
MAXIMUM PERMISSIBLE LIMITS ON \\
\multicolumn{5}{c}{$\begin{array}{l}\text { SELECTED HEAVY METALS }\left(\mu \mathrm{g} \mathrm{g}^{-1}\right) \text { FOR FOOD } \\
\text { SAFETY SET BY DIFFERENT COUNTRIES }\end{array}$} \\
\hline \multicolumn{1}{c}{ Limit values } & $\begin{array}{c}\text { Weight } \\
\text { basis }\end{array}$ & $\mathrm{Hg}$ & $\mathrm{Pb}$ & $\mathrm{Cd}$ & Ref. \\
\hline Brazil & Dry & & 10 & 5 & {$[23]$} \\
Thailand & Dry & & 6.67 & & {$[24]$} \\
European Community & Wet & 0.5 & 1.5 & 1 & {$[25]$} \\
Hong Kong & Wet & & 6 & 2 & {$[26]$} \\
Australia & Wet & & 2 & 2 & {$[27]$} \\
USA & Wet & 1 & 1.7 & 3.7 & {$[28]$} \\
Malaysia & Wet & 0.5 & 2 & 1 & {$[29]$} \\
\hline
\end{tabular}

TABLE-7

\begin{tabular}{ccc} 
TABLE-7 \\
\multicolumn{4}{c}{ MEAN VALUES OF RARE EARTH ELEMENTS } \\
CONCENTRATION $\left(\mu \mathrm{g} \mathrm{g}^{-1}\right)$ IN WET AND DRY \\
\multicolumn{3}{c}{ STATES OF SOFT TISSUE OF S. cucullata } \\
\hline Element & Wet & Dry \\
\hline $\mathrm{La}$ & 0.35 & 1.88 \\
$\mathrm{Ce}$ & $1.02^{*}$ & 5.44 \\
$\mathrm{Pr}$ & 0.14 & 0.76 \\
$\mathrm{Nd}$ & $0.59^{*}$ & 3.14 \\
$\mathrm{Sm}$ & 0.13 & 0.71 \\
$\mathrm{Eu}$ & 0.02 & 0.15 \\
$\mathrm{Gd}$ & 0.14 & 0.74 \\
$\mathrm{~Tb}$ & 0.02 & 0.12 \\
$\mathrm{Dy}$ & 0.08 & 0.46 \\
$\mathrm{Ho}$ & 0.01 & 0.08 \\
$\mathrm{Er}$ & 0.03 & 0.19 \\
$\mathrm{Tm}$ & 0.00 & 0.03 \\
$\mathrm{Yb}$ & 0.02 & 0.10 \\
$\mathrm{Lu}$ & 0.00 & 0.01 \\
\hline
\end{tabular}

Health of Thailand, the Commission Europe, the Hong Kong Environmental Protection Department, the Food Standards Australia New Zealand Authority, the Australian Government and the Food and Drug Administration of the United States.

The results of the comparative analysis indicate that $\mathrm{Ce}$ and $\mathrm{Nd}$ concentrations in rock oyster $S$. cucullata are higher than the food security limits set. $S$. cucullata is one of important food sources consumed in Malaysia [30]. However, the consideration whether this oyster is unsafe for consumption is debatable as other elements across REEs series did not pose high levels. Though there is no report on occurrences of human poisoning over marine organisms food chain.

Potential anxieties concerning effects of constant exposure to low levels of REEs on human health have been ascending. It has been reported that REEs are significantly accumulated in blood, brain and bone after entering human body [31-34]. Regarding the effects of REEs to the human body, studies reported by Arvela et al. [35,36] and Zhu et al. [37] indicated that high exposure levels might be connected to health problems, for instance, liver function declining. It can be concluded that the consumption of studied organisms should not result in an excessive volume that might be damaging to human health, nevertheless, the long-time effects of REEs on human beings should be taken into account.

\section{Conclusions}

From the present study, the followings can be concluded:

- The bivalve mollusc, S. cucullata possessed high potential as cosmopolitan bioindicators for REEs due to its 
feeding behaviour that relates well to REEs sources. The samples taken from this study could be considered representative for background concentration in the Malaysian rocky shore environment

- Consistent chondrite-normalized patterns suggested that light REEs and heavy REEs fractionation in coastline marine environment produces more light REEs and less heavy REEs. Correspondingly, the enrichment of LREE in selected species is consistent throughout the rocky shore areas. Ce and Eu show consistent anomalies behaviour from the other REEs as a result of their redox chemistry. The REEs fractionation patterns normalized to chondrite and shale were remarkably similar indicating a common source of the REEs.

- The consumption of studied organisms should not result in an excessive volume that might be damaging to human health, nevertheless, the long-term effects of REEs on human beings should be taken into account, as species in this study are related with human consumption.

\section{ACKNOWLEDGEMENTS}

The authors express their gratitude to Malaysian Ministry of Science, Technology and Innovation (MOSTI) and International Islamic University Malaysia (IIUM) for research grant and facility.

\section{REFERENCES}

1. J. Riondato, F. Vanhaecke, L. Moens and R. Dams, J. Anal. Chem., 370, 544 (2001); https://doi.org/10.1007/s002160100801.

2. M. Costas, I. Lavilla, S. Gil, F. Pena, I. de la Calle, N. Cabaleiro and C. Bendicho, Anal. Chim. Acta, 679, 49 (2010); https://doi.org/10.1016/j.aca.2010.09.004.

3. P.S. Rainbow, Environ. Pollut., 120, 497 (2002); https://doi.org/10.1016/S0269-7491(02)00238-5.

4. Y. Wang, L. Liang, J. Shi and G. Jiang, Environ. Int., 31, 1103 (2005); https://doi.org/10.1016/j.envint.2005.02.005.

5. A.R. Abdullah, N.M. Tahir, T.S. Loong, T.M. Hoque and A.H. Sulaiman, Mar. Pollut. Bull., 39, 229 (1999);

https://doi.org/10.1016/S0025-326X(98)00206-9.

6. N.A.M. Shazili, K. Yunus, A.S. Ahmad, N. Abdullah and M.K.A. Rashid, Aquat. Ecosyst. Health Manage., 9, 137 (2006); https://doi.org/10.1080/14634980600724023.

7. P. Bustamante and P. Miramand, Sci. Total Environ., 337, 59 (2005); https://doi.org/10.1016/j.scitotenv.2004.07.004.

8. B.Y. Kamaruzzam, M.S. Zahir, B.A. John, A.S. Waznah, K.C.A. Jalal, S. Shahbudin, S.M. Al-Barwani and J.S. Goddard, Pak. J. Biol. Sci., 13, 1208 (2010); https://doi.org/10.3923/pibs.2010.1208.1213.

9. Y. Kamaruzzaman, Nurul Nadia, Noor Azhar, M. S. Shahbudin and S. Bidai, J. Sains Malay., 40, 827 (2011).

10. W.F. McDonough and S.S. Sun, Geological Society of London, pp 313-345 (1989).

11. S.R. Taylor and S.M. McLennan, The Continental Crust: Its Composition and Evolution, Blackwell Scientific Publishers, Oxford, pp. 312 (1985).

12. H.J.W. DeBaar, M.P. Bacon, P.G. Brewer and K.W. Bruland, Geochim. Cosmochim. Acta, 49, 1943 (1985); https://doi.org/10.1016/0016-7037(85)90089-4.
13. C.J. Bertram and H. Elderfield, Geochim. Cosmochim. Acta, 57, 1957 (1993); https://doi.org/10.1016/0016-7037(93)90087-D

14. Y. Nozaki, D.S. Alibo, H. Amakawa, T. Gamo and H. Hasumoto, Geochim. Cosmochim. Acta, 63, 2171 (1999); https://doi.org/10.1016/S0016-7037(99)00142-8.

15. S. Ohde and J.P. Mataragio, J. Radioanal. Nucl. Chem., 240, 325 (1999); https://doi.org/10.1007/BF02349172.

16. K.M. Towe, Palaeogeogr. Palaeoclimatol. Palaeoecol., 97, 113 (1991); https://doi.org/10.1016/0031-0182(91)90187-V.

17. L. Weltje, H. Heidenreich, W. Zhu, H.T. Wolterbeek, S. Korhammer, J.J.M. de Goeij and B. Markert, Sci. Total Environ., 286, 191 (2002); https://doi.org/10.1016/S0048-9697(01)00978-0.

18. G. Chaillou, P. Anschutz, G. Lavaux and G. Blanc, Mar. Chem., 100, 39 (2006); https://doi.org/10.1016/j.marchem.2005.09.007.

19. K. Rezaee, E.B. Saion, K. Wood and M.R. Abdi, J. Radioanal. Nucl. Chem., 283, 823 (2010); https://doi.org/10.1007/s10967-009-0421-z.

20. B. Wisely and B.L. Reid, Aquaculture, 15, 319 (1978); https://doi.org/10.1016/0044-8486(78)90078-9.

21. K. Sultan and N.A. Shazili, J. Rare Earths, 27, 1072 (2009); https://doi.org/10.1016/S1002-0721(08)60391-9.

22. F.E.C. Sneller, D.F. Kalf, L. Weltje and A.P. Van Wezel, National Institute of Public Health and the Environment, Bilthoven, Report No. RIVM 601501011 (2000).

23. ABIA (Associacao Brasileira das Industrias de Alimentacao), Brazilian Food Industries Association, (1991).

24. MPHT (Ministry of Public Health and Medical Research Council), Residues in Foods, Part 23. The Government Gazette, Bangkok, Thailand, vol. 103, pp. 1123-1124 (special issue) (1986).

25. CE (Commission Europeénne), Regulation (CE) No. 1881/2006 of 19 December 2006; Setting Maximum Levels for Certain Contaminants in Foodstuffs, Official Journal of the European Union, L 364/5 du 20 December (2006)

26. HKEPD (Hong Kong Environmental Protection Department), Marine Water Quality in Hong Kong in 1997, Government Printer Hong Kong (1997).

27. FSANZ (Food Standards Australia New Zealand), Final Assessment Report: Proposal P230, Consideration of Mandatory Fortification with Iodine for New Zealand (2008).

28. USFDA (Food and Drug Administration of the United States), US Food and Drug Administration Shellfish Sanitation Branch, Washington, DC (1990).

29. Malaysian Food Regulation, Fourteenth Schedule, Malaysian Law on Food and Drugs, Malaysian Law Publishers (1985).

30. C.K. Yap, S. Mohd Ruszaidi and W.H. Cheng, Res. J. Chem. Environ., 14, 17 (2010).

31. Z.K. Yuan, Y. Liu, H.Q. Yu, H.L. Zheng, N.F. Wang, M.K. Wu, Y.T. Liu and S.M. Yan, China Pub. Health, 19, 133 (2003).

32. Z.Y. Chen, Rural Eco-Environ., 21, 72 (2005)

33. Z.Y. Chen and X.D. Zhu, J. Ecol. Rural Environ., 24, 88 (2008).

34. L. d'Aquino, M. Morgana, M.A. Carboni, M. Staiano, M.V. Antisari, M. Re, M. Lorito, F. Vinale, K.M. Abadi and S.L. Woo, Soil Biol. Biochem., 41, 2406 (2009); https://doi.org/10.1016/j.soilbio.2009.08.012.

35. P. Arvela, O. Grajewski, B. v. Lehmann and E. Oberdisse, Experientia, 33, 491 (1976); https://doi.org/10.1007/BF01922228.

36. P. Arvela, B.V. Lehmann, O. Grajewski and E. Oberdisse, Experientia, 36, 860 (1980); https://doi.org/10.1007/BF01978615.

37. W.F. Zhu, S.Q. Xu, P.P. Shao, H. Zhang, D.S. Wu, W.J. Yang, J. Feng and L. Feng, Biol. Trace Elem. Res., 104, 1 (2005); https://doi.org/10.1385/BTER:104:1:001. 